Archivos
de Cardiología
de Méxíco

IMÁGENES EN CARDIOLOGÍA

\title{
Depósitos de mercurio como hallazgo tomográfico incidental en un índice de calcio coronario
}

\author{
Mercury deposits as incidental CT findings on a coronary calcium score \\ José J. Lozoya del Rosal*, Francisco J. Azar-Manzur, Christian Buelna-Cano y Enrique Vallejo \\ Departamento de Centro Cardiovascular, Centro Médico ABC, Ciudad de México, México
}

Varón de 47 años referido a nuestro centro para realizar un índice de calcio coronario. Como antecedente de relevancia refiere intento suicida con inyección de mercurio elemental intravenoso. Las imágenes tomográficas sin contraste del corazón mostraron evidencia de calcio en la circunfleja (11 unidades Agatston) y en la coronaria derecha (28 unidades Agatston). Se identificaron depósitos metálicos difusos en las imágenes exploratorias (Fig. 1). Los depósitos metálicos también se observaron en el ventrículo derecho y en el pulmón, ambos compatibles con mercurio (Fig. 2). La intoxicación por mercurio es un evento raro, generalmente asociado a intentos suicidas o inyecciones accidentales ${ }^{1}$. El mercurio puede causar toxicidad aguda 0 crónica, debido a daño tanto embólico como químico en pulmones, corazón, riñón, hígado y cerebro; el curso crónico puede cursar sin toxicidad clínica².

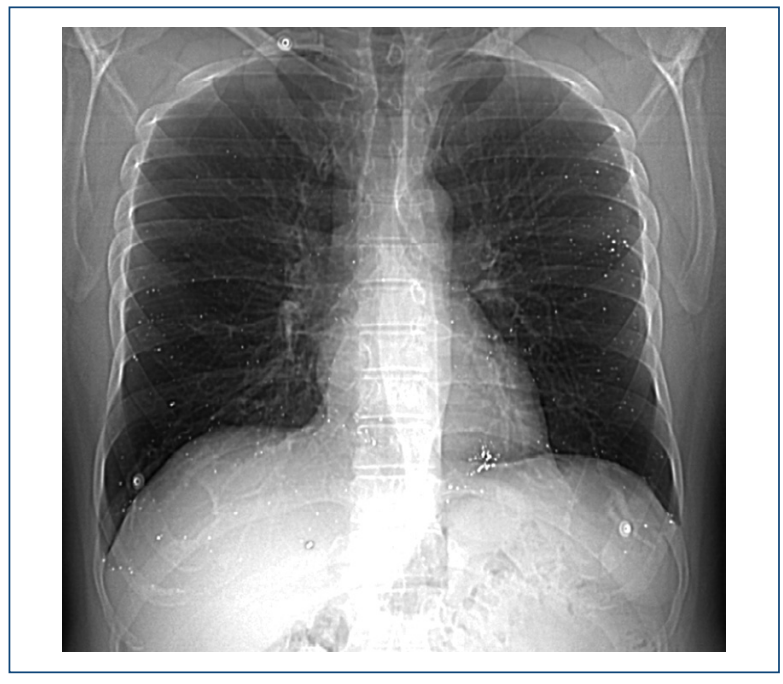

Figura 1. Imágenes que evidencian depósitos metálicos en el pulmón y en el corazón.
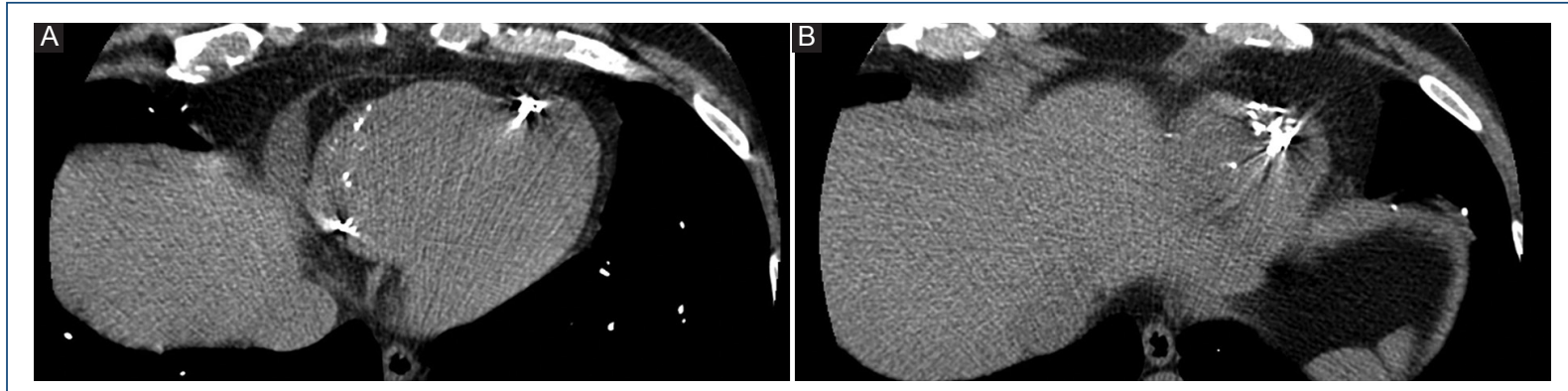

Figura 2. Imágenes tomográficas no contrastadas del corazón que demuestran depósitos metálicos en la pared lateral (A) y en el ápex del ventrículo derecho (B).

\section{Correspondencia:}

*José J. Lozoya del Rosal

E-mail: pepeloz@gmail.com
Fecha de recepción: 19-03-2020

Fecha de aceptación: 18-05-2020 DOI: 10.24875/ACM.20000127
Disponible en internet: 03-11-2020 Arch Cardiol Mex. 2021;91(2):240-241 www.archivoscardiologia.com 1405-9940 / @ 2020 Instituto Nacional de Cardiología Ignacio Chávez. Publicado por Permanyer. Este es un artículo open access bajo la licencia CC BY-NC-ND (http://creativecommons.org/licenses/by-nc-nd/4.0/). 


\section{Conflicto de intereses}

Ninguno.

\section{Financiamiento}

La presente investigación no ha recibido ninguna beca específica de agencias de los sectores público, comercial o sin ánimo de lucro.

\section{Responsabilidades éticas}

Protección de personas y animales. Los autores declaran que para esta investigación no se han realizado experimentos en seres humanos ni en animales.
Confidencialidad de los datos. Los autores declaran que han seguido los protocolos de su centro de trabajo sobre la publicación de datos de pacientes.

Derecho a la privacidad y consentimiento informado. Los autores declaran que en este artículo no aparecen datos de pacientes.

\section{Bibliografía}

1. Bach AG, Restrepo CS, Abbas J, Villanueva A, Lorenzo Dus MJ, Schöpf R, et al. Imaging of nonthrombotic pulmonary embolism: biological materials, nonbiological materials, and foreign bodies. Eur J Radiol. 2013;82:e120-41.

2. Gutiérrez F, Leon L. Images in clinical medicine. Elemental mercury embolism to the lung. N Engl J Med. 2000;342:1791. 